\title{
Isolation and Identification of Polystyrene Degrading Bacteria from Zophobas morio's Gut
}

\author{
Kian Meng TAN ${ }^{1}$, Noor Akhmazillah MOHD FAUZI ${ }^{1, *}$, \\ Angzzas Sari MOHD KASSIM ${ }^{1}$, Aliff Hisyam A RAZAK ${ }^{1}$ and \\ Kamarul Rahim KAMARUDIN ${ }^{2}$
}

\author{
${ }^{I}$ Department of Chemical Engineering Technology, Universiti Tun Hussein Onn Malaysia, \\ Jalan Panchor, Panchor 84600, Johor, Malaysia \\ ${ }^{2}$ Department of Technology and Natural Resources, Faculty of Applied Sciences and Technology, \\ Universiti Tun Hussein Onn Malaysia, Jalan Panchor, Panchor 84600, Johor, Malaysia
}

( Corresponding author's e-mail: akhma@uthm.edu.my)

Received: 7 November 2019, Revised: 20 May 2020, Accepted: 20 June 2020

\begin{abstract}
Polystyrene (PS) and expanded polystyrene (EPS) are commodity plastics widely used in many industries. The increase of PS in the environment causes ecological threats. It has been observed that the beetle larvae feed on plastic packages, and this has drawn the researcher's attention towards the complex system within the larvae's gut where relationships between fungi, bacteria, and the insect host have been established. The objective of this study is to isolate and identify PS-degrading microbe from super worms. The study used polystyrene as a sole carbon source to isolate the positive PS-degrading bacteria. Five bacterial colonies which showed positive growth on the modified PS-agar plate were isolated. All five colonies of the PS-degrading bacterial isolates were identified using partial $16 \mathrm{~S}$ rRNA gene sequencing. The results showed a close relationship between Bacillus aryabhattai and Bacillus megaterium strains. An examination via biochemical studies for distinction was implemented further. Based on the morphological characterization and taxonomic method, the isolates were identified as Bacillus megaterium. The isolates' viability was tested using 2,3,5-triphenyltetrazolium chloride (TTC), and positive results were obtained with red-colored insoluble triphenylformazan (TPF) formed within 5 to 7 days. The isolation and identification of these bacteria from Zophobas morio's gut may provide a promising source of a plastic degrading enzyme that can be further studied and manipulated in developing enzymatic biodegradation in plastic waste management.
\end{abstract}

Keywords: Isolation, Polystyrene, PS-degrading bacteria, Zophobas morio, 16 S rRNA sequencing

\section{Introduction}

In recent years, the daily use of petroleum-based plastic products has been reduced globally. In Malaysia, the "No Plastic Bag Day" campaign has been launched by the Ministry of Domestic Trade, Cooperative and Consumerism to cut down excessive usage of plastic bags since the year 2011 [1]. To date, a few states in Malaysia (e.g., Kuala Lumpur, Putrajaya, Selangor, Malacca, Penang, and Johor) have enforced the "No Plastic Bag Day" campaign [2]. All these states have banned the use of polystyrene (PS) food containers and replaced them with polyethylene (PE) food containers. Such an initiative aims to raise public awareness of the serious adverse effects of poor plastic waste management and introduce a nationwide ban on plastic products in the future. Nevertheless, such momentarily efforts will not be sufficient to address the existing plastic wastes in our landfill. At present, Malaysia is still very dependent on landfills as the main method of waste disposal. There are over $80 \%$ of the collected 
http://wjst.wu.ac.th

municipal solid wastes (MSW) are landfilled. Plastic waste represents the 2nd largest portion of MSW which accounted for about $24 \%$. Nevertheless, in the near future, landfills will be unable to cope with the growing MSW generation rate, as the current landfills are approaching the maximum capacity limit and scarcity of land, making it hard to establish new dumpsites [3].

Recycling is a feasible alternative to landfills. In fact, plastics are one of the most common recyclable materials because of their high recycling potential. However, the recycling rate in Malaysia is low. Recycling industries in Malaysia focus on materials that can be collected easily and have high market value. As a result, low recycling value waste materials such as food packaging, polystyrene products (Styrofoam), and straws are often not recycled and ended in the landfills [4]. Likewise, incineration has been an alternative to landfills for MSW treatment and to gather emitted methane gas $\left(\mathrm{CH}_{4}\right)$ from waste as a source of energy [5]. In Malaysia, incineration plants used as waste to energy (WTE) only present on a very small scale and limited quantity. There are several hurdles associated with waste incineration technology to be widely used in Malaysia: Release of pollutant to the atmosphere through the exhaust gas, large investment required which making it more expensive than landfilling and high moisture content in Malaysian MSW, drying of waste is performed with energy expenses [6]. Thus, concerning the scarcity of land, there is a need for a better and effective plastic waste management strategy for landfills despite the existing waste management, such as conventional landfilling, incineration, and recycling.

The biological decomposition of PS using microorganisms seems to be a promising approach towards environmentally friendly waste management. It is regarded as the safest approach that anticipates producing non-toxic by-products and has the potentials of bio-geochemical cycling of the substrate [7]. The by-products formed after decomposition are mainly $\mathrm{CO}_{2}, \mathrm{CH}_{4}, \mathrm{H}_{2} \mathrm{O}$, and biomass which are relatively non-toxic to both nature and living organisms. Although there are limited studies on the biodegradation of PS, a few research studies have reported the microbial decomposition of its monomer, styrene, namely: Bacteria strains [8], fungi [9], and mixed culture and enzyme [10], which have been used in the experimental biodegradation of PS under different conditions. Recent studies have also suggested that a few microorganisms (bacteria and fungi) isolated from the soil began to form biofilm when incubated with PS-film. This revealed their ability to biodegrade PS [11]. Additionally, studies focused on manipulating insects found in storehouses and kitchens have shown that these insects can masticate and munch plastic packages [12-14]. Yang et al. [15] reported that the larvae of mealworms (Tenebrio molitor Linnaeus, Coleoptera: Tenebrionidae) could consume Styrofoam. By taking advantage of such PS-eating mealworms, they have explored the gut of mealworms and identified a novel bacterium, YT2, which belongs to Exiguobacterium sp. and other 12 isolates based on its $16 \mathrm{~S}$ rRNA sequences.

Similarly, the larvae of Zophobas morio, commonly known as superworm, belong to the same family of Tenebrionidae, could survive by consuming solely on Styrofoam. Therefore, it can be concluded that the guts of the beetle larvae constitute a complex system where certain bacteria and the insect host are actively degrading the Styrofoam. This rapid biodegradation of PS inside the larval gut provides a new impetus for the biodegradation of the plastic waste existing in our environment. This study aimed to isolate PS-degrading bacteria from the midgut of Zophobas morio and identify the bacteria using partial $16 \mathrm{~S}$ rRNA gene amplification and sequencing.

\section{Materials and methods}

\section{Sampling (EPS \& superworm)}

The expanded polystyrene (EPS) feedstocks tested for biodegradation were collected as recycling waste from a local electrical appliance shop in Parit Raja, Batu Pahat, Johor, Malaysia. The superworms (larvae of Zophobas morio) at their growth age of approximately 3 - 4 instars were purchased from a local worm breeding farm located in Layang-Layang district, Johor, Malaysia, to investigate its plastic degrading strain found in the worm's gut. 


\section{Liquid Carbon Free Basal Medium (LCFBM)}

The LCFBM medium was used in compliance to the American Society for Testing and Materials (ASTM) standard for studying the bacteria resistance to plastics (ASTM G22-76). Medium was prepared in deionized water containing a chemical mixture consisting of $0.7 \mathrm{gL}^{-1}$ dipotassium phosphate $\left(\mathrm{K}_{2} \mathrm{HPO}_{4}\right)$, $0.7 \mathrm{gL}^{-1}$ potassium phosphate $\left(\mathrm{KH}_{2} \mathrm{PO}_{4}\right), 0.002 \mathrm{gL}^{-1}$ sodium chloride $(\mathrm{NaCl}) ; 0.005 \mathrm{gL}^{-1}$ ammonium nitrate $\left(\mathrm{NH}_{4} \mathrm{NO}_{3}\right), 1.0 \mathrm{gL}^{-1}$ magnesium sulphate $\left(\mathrm{MgSO}_{4} \cdot 7 \mathrm{H}_{2} \mathrm{O}\right) ; 0.001 \mathrm{gL}^{-1}$ zinc sulphate $\left(\mathrm{ZnSO}_{4} \cdot \mathrm{H}_{2} \mathrm{O}\right)$; $0.001 \mathrm{gL}^{-1}$ manganate sulphate $\left(\mathrm{MnSO}_{4} \cdot \mathrm{H}_{2} \mathrm{O}\right) ; 0.002 \mathrm{gL}^{-1}$ ferum sulphate, $\left(\mathrm{FeSO}_{4} \cdot 7 \mathrm{H}_{2} \mathrm{O}\right)$.

\section{Preparation of polystyrene emulsion and agar}

The PS emulsion for microbial degradation was prepared where waste EPS feedstocks were $1^{\text {st }}$ dissolved in dichloromethane solvent at $3 \%$. Then, $100 \mathrm{~mL}$ of the solution was transferred to $250 \mathrm{~mL}$ of amber bottle with $100 \mathrm{~mL}$ LCFBM stored in the laboratory chiller at $4{ }^{\circ} \mathrm{C}$ for 2 days. After 2 days, the PS emulsion was placed in a fume hood overnight to volatilize the dichloromethane solvent [16]. The PS agar was prepared by transferring $50 \mathrm{~mL}$ of PS emulsion to a $250 \mathrm{~mL}$ Erlenmeyer flask containing $50 \mathrm{~mL}$ LCFBM with $1.5 \mathrm{~g}$ of agar powder and autoclaved at $121{ }^{\circ} \mathrm{C}$ for $15 \mathrm{~min}$. Then, it was poured into sterilised petri dishes.

\section{Preparation of culture enrichment}

A sample of 50 superworms was fed with EPS as their sole diet for two weeks (Figure 1) prior to preparing PS-degrading bacteria enrichment. Initially, the sterilization was carried out by immersing the beetle larvae in $75 \%$ ethanol for $1 \mathrm{~min}$, followed by rinsing with sterile $0.85 \%$ saline water two times before the dissection process to remove the entire gut from each larva and placed it on a sterile Petri dish. Then, the midguts were drawn out and pooled into a $10 \mathrm{~mL}$ centrifuge tube containing $5 \mathrm{~mL}$ of saline water. After being homogenised on a vortex mixer for $10 \mathrm{~min}$, the gut tissues were removed using a pipette. The collected gut cell suspension was used as the inoculum of PS-degrading bacterial culture enrichment. The gut cell suspension was transferred to a $250 \mathrm{~mL}$ Erlenmeyer flask containing $20 \mathrm{~mL}$ PS emulsion as sole carbon and $80 \mathrm{~mL}$ of LCFBM. Then, the flasks were incubated on a rotary shaker at 120 rpm and temperature at $30^{\circ} \mathrm{C}$ for 28 days.

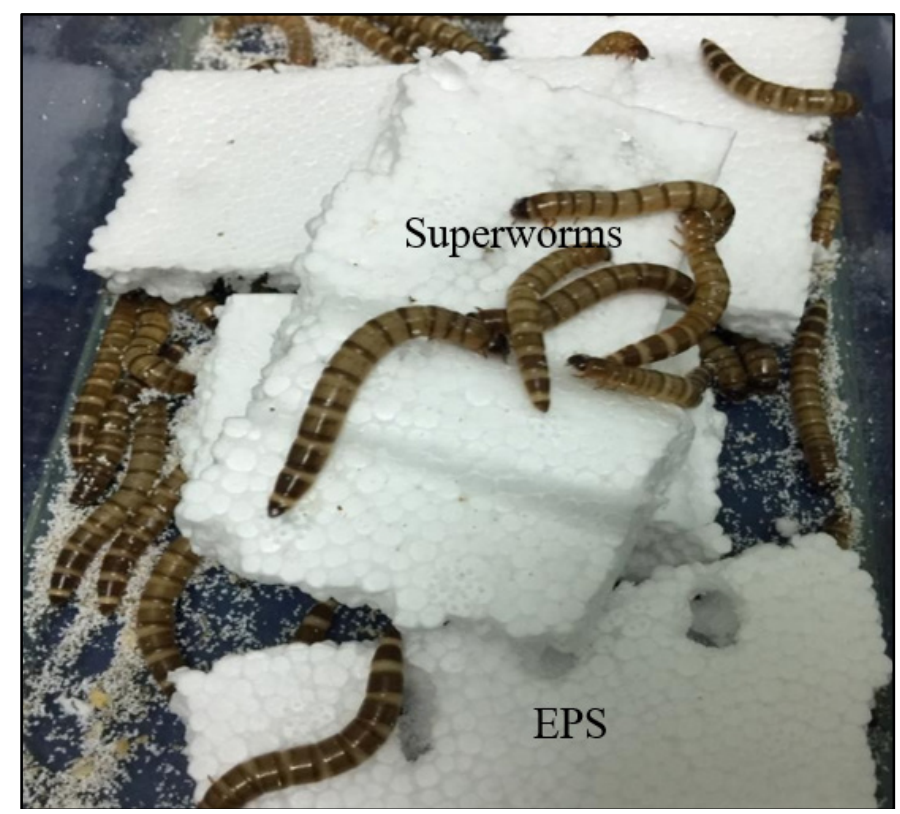

Figure 1 Superworms were fed solely on EPS diet for 2 weeks. 


\section{Isolation and identification of isolates}

After 28 days of incubation, the enrichment was spread on modified PS agar plates and then incubated at ambient temperature for $24 \mathrm{~h}$ to enumerate the number of bacteria present in the enrichment culture. Then, three colonies from each plate were chosen based on cell morphology (shape, color, size) and streaked on other fresh PS agar plates for sub-culturing repeatedly until pure colonies of isolates were obtained [17]. Enrichment media were used, followed by PS selective agar, to isolate a single colony of interest. The bacteria colony growth on the PS-agar plate was Gram-stained and viewed under a light microscope at $40 \mathrm{X}$ magnification for bacteria characterization and to get an overview of the cell morphology (shape, size, and color).

\section{DNA extraction}

DNA extraction was done by using a DNA extraction kit provided by First Base Laboratories Sdn. Bhd., Malaysia. First, bacterial cells in the late exponential phase were harvested via centrifugation $\left(10,000 \times \mathrm{g} ; 4{ }^{\circ} \mathrm{C} ; 15 \mathrm{~min}\right)$ and resuspended in $567 \mathrm{~mL}$ TE lysis buffer $(10 \mathrm{mM}$ Tris, one mM EDTA; pH 8.0). Then, the proteins were degraded with $3 \mathrm{~mL}$ proteinase $\mathrm{K}(2 \% \mathrm{w} / \mathrm{v})$ and $30 \mathrm{~mL}$ of sodium dodecyl sulfate $(10 \% \mathrm{wt} / \mathrm{vol})$ incubated at $37{ }^{\circ} \mathrm{C}$ for $60 \mathrm{~min}$. Next, the addition of a binding buffer consisting of $100 \mathrm{~mL}$ sodium chloride $(5 \mathrm{M})$ and $80 \mathrm{~m} \mathrm{LCTAB} / \mathrm{NaCl}(10 \% \mathrm{w} / \mathrm{v} \mathrm{CTAB}, 0.7 \mathrm{M} \mathrm{NaCl})$ and incubation for $10 \min 65^{\circ} \mathrm{C}$ in a water bath. An equal volume of chloroform/isoamyl alcohol (24:1) was added to the mixture and centrifuged $\left(12,000 \times \mathrm{g} ; 4^{\circ} \mathrm{C} ; 5 \mathrm{~min}\right)$ to precipitate polysaccharides. The supernatant was collected, and the same volume of phenol/chloroform/isoamyl alcohol (25:24:1) was added. The solution was mixed thoroughly and centrifuged $\left(12,000 \times \mathrm{g} ; 4{ }^{\circ} \mathrm{C} ; 5 \mathrm{~min}\right)$ to precipitate out proteins, and the supernatant was collected. Finally, precipitation of DNA was carried by adding isopropanol to the supernatant collected. The mixture was centrifuged $\left(12,000 \times \mathrm{g} ; 4^{\circ} \mathrm{C} ; 5 \mathrm{~min}\right)$. The DNA precipitate was resuspended in $100 \mathrm{~mL}$ TE buffer and stored at $-20{ }^{\circ} \mathrm{C}$ for further analysis.

\section{PCR amplification}

The bacterial $16 \mathrm{~S}$ rRNA, full-length $1.5 \mathrm{~kb}$, was amplified with the universal primers $27 \mathrm{~F}$ ( $5^{\prime}$ AGAGTTTGATCMTGGCTCAG 3') and 1492R (5' TACGGYTACCTTGTTACGACTT 3'). The total reaction volume of $25 \mathrm{uL}$ gDNA was purified using the in-house extraction method, $0.3 \mathrm{pmol}$ of each primer, deoxynucleotides triphosphates (dNTPs, $400 \mathrm{uM}$ each), $0.5 \mathrm{U}$ DNA polymerase, supplied PCR buffer, and water. The PCR was performed as follow: 1 cycle $\left(94{ }^{\circ} \mathrm{C}\right.$ for $\left.2 \mathrm{~min}\right)$ for initial denaturation; 25 cycles $\left(98{ }^{\circ} \mathrm{C}\right.$ for $10 \mathrm{~s} ; 53{ }^{\circ} \mathrm{C}$ for $30 \mathrm{~s} ; 68^{\circ} \mathrm{C}$ for $\left.1 \mathrm{~min}\right)$ for annealing and extension of the amplified DNA. The PCR products were purified by standard method and directly sequenced with the primers 785F (5' GGATTAGATACCCTGGTA 3') and 907-R (5' CCGTCAATTCMTTTRAGTTT 3') using the BigDye ${ }^{\circledR}$ Terminator v3.1 Cycle Sequencing Kit (Applied Biosystems).

\section{PCR product analysis}

$5 \mu \mathrm{L}$ of the PCR products were electrophoresed in $1.0 \%$ agarose gel at $100 \mathrm{~V}$ for $45 \mathrm{~min}$, and the gel was stained in $100 \mathrm{~mL}$ of TAE solution and five $\mu \mathrm{L}$ of ethidium bromide and then placed on a rocker for 20 - $30 \mathrm{~min}$. The EtBr solution was replaced with water to destain the gel for $5 \mathrm{~min}$. The PCR bands were visualized under a UV illuminator (UVP FirstLight, USA). A 1-kb DNA molecular ladder (DNA fragment ranging 250 - $10000 \mathrm{bp}$, Gold Bio, USA) was added to determine the amplified PCR products' size.

\section{Phylogenetic tree construction}

The $16 \mathrm{~S}$ rRNA sequences obtained were viewed using the Chromas 2.6.6 software. The Basic Local Alignment Search Tool (BLAST) was used to analyse the obtained sequence with organisms in the GenBank database for strain identification and construction of phylogenetic tree analysis. The phylogenetic tree and molecular evolutionary analyses were constructed using the MEGAX software with the neighbour joining algorithm. The percentage of replicate trees in which the associated taxa clustered together in the bootstrap test (1000 replicates) was indicated next to the branches. The evolutionary distances were computed using the maximum composite likelihood method [18]. 


\section{Primary screening of isolates viability and metabolic activity}

The five bacterial isolates were assayed for their ability to utilize PS as the sole source of carbon. Each isolate was cultured in LCFBM supplemented with emulsified PS; $2 \%$ of glucose was added into the positive control medium, and non-inoculum sample culture was served as a negative control. The metabolic activity was investigated by adding an aliquot of $20 \mu \mathrm{L}$ of $1 \% 2,3,5$-triphenyltetrazolium chloride (TTC) reagent to $5 \mathrm{~mL}$ of culture medium viability indicator [19]. It was expected that the PSdegrading bacteria were capable of surviving solely on PS in the medium. The enzymes in the bacteria's electron transport chain converted the colorless TTC into red coloured triphenyl formazan (TPF). Bacteria viability is relatively correlated to active metabolic bacteria converting carbon source PS to provide energy for the vital process.

\section{Results and discussion}

All the colonies growth on the basal PS agar plate were observed to have a white and creamy circular shape, as shown in Figure 2. The investigation proceeded with a general observation of the bacteria's shape using a light microscope alongside Gram staining. The results showed the five colonies isolated (labeled A, B, C, D, and E) from the basal PS agar viewed under a microscope at 40X magnification were rod-shaped with more than $5 \mu \mathrm{m}$ long and positive Gram-stained as shown in Figure 3.

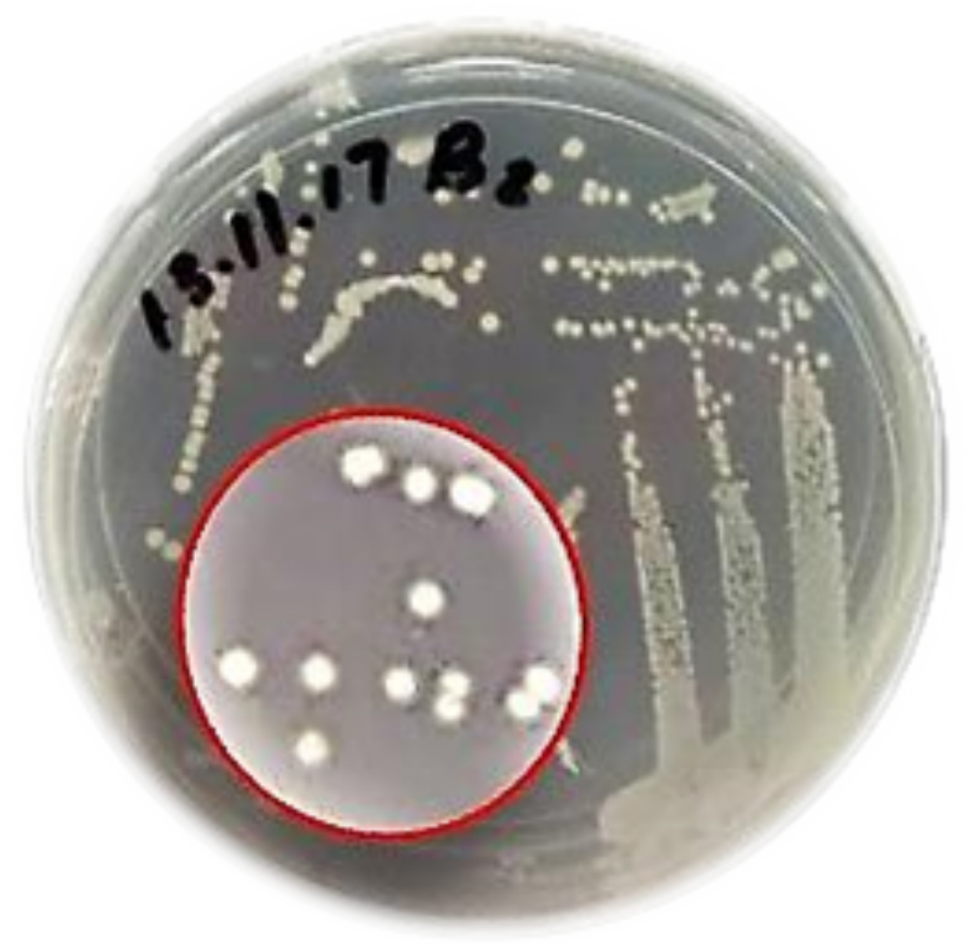

Figure 2 Colonies growth on basal PS agar plate. 


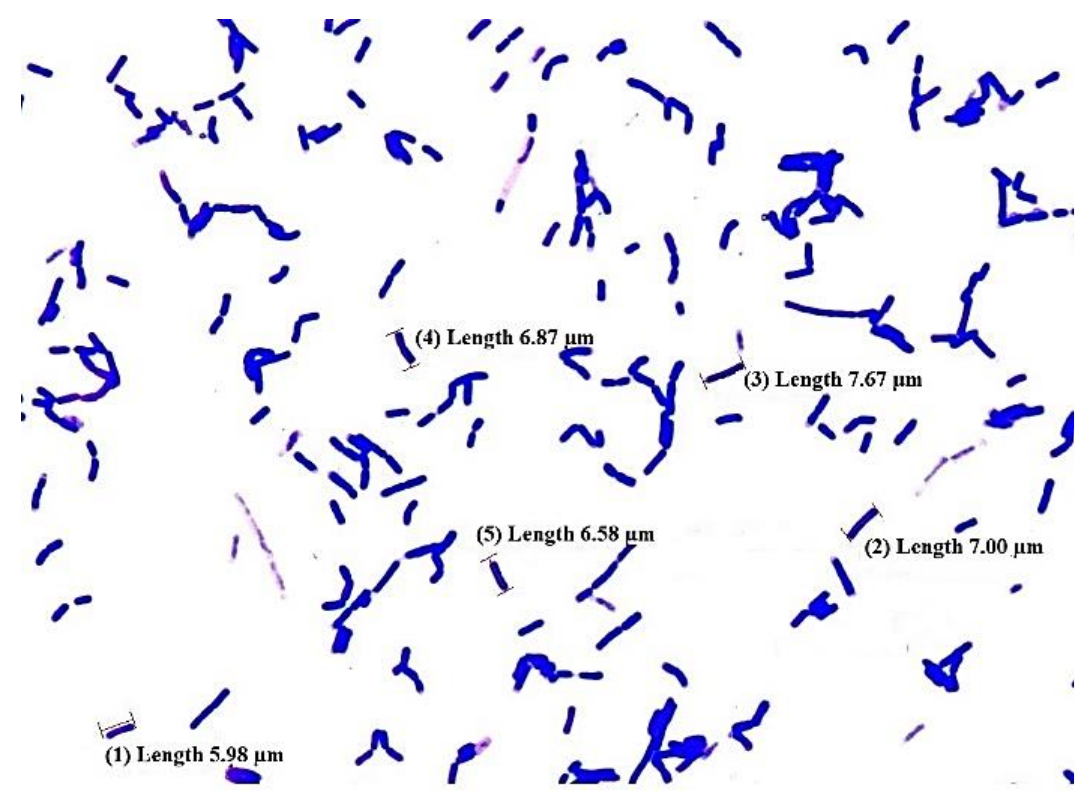

Figure 3 Morphological characteristics of bacteria isolate view under microscope at 40X magnification.

Preliminary, the morphological characteristic of the isolates drawn a clear assumption that the bacteria found was of genus Bacillus as Bacillus species are rod-shaped and Gram-positive bacteria [20], [21]. Moreover, the bacteria Bacillus sp. (Bacillus subtilis, Bacillus cereus, and Bacillus brevis) have also been linked to polymer degradation processes involving various polymers such as polyethylene polycaprolactone and polylactic acid [22]. Furthermore, concerning polymer degradation ability, this indicated a rather conclusive identity that the bacteria isolated belongs to the Bacillus genus.

In order to ascertain the identity of the bacteria, amplification, and sequencing of partial $16 \mathrm{~S}$ rRNA gene were done. Based on the PCR assay, DNAs extracted from PS degrading bacteria (labelled A, B, C, $\mathrm{D}$, and E) gave the estimated $1600 \mathrm{bp}$ PCR fragment of $16 \mathrm{~S}$ rRNA (Figure 4). The partial $16 \mathrm{~S}$ rRNA sequence, when compared with the top 10 BLAST database entries, revealed that all five isolates showed $99 \%$ similar characteristics with the sequence of Bacillus aryabhattai strain, Bacillus megaterium strain, and Bacillus sp. strain MH 9 as summarized in Table 1. The bootstrap consensus tree constructed (Figure 5) showed the phylogenetic relationship of the five isolates with the related species and gave a deeper insight that the five isolates were closely identical to the Bacillus aryabhattai strain IHB 11068 (KR 085848.1) and Bacillus megaterium strain MP 8 (KX 298860.1). In addition, the taxonomic identification using MEGA X [18] revealed that the isolates (A, B, C, D, and E) reveal the closest phylogenetic relationship to the Bacillus megaterium strain IHB B 7295 (KJ 767362.1) as they shared the common ancestor.

With reference to previous literature on the biodegradation of aromatic compounds, Bacillus megaterium strain in the oil-contaminated sites was believed to metabolise both n-alkanes and aromatic hydrocarbons in petroleum [23,24]. It has also been reported that Bacillus megaterium is a lignin peroxidase producing bacteria which indicated its potential in lignin degradation [25]. In addition, Buraimoh et al. [26] stated that Bacillus megaterium strain NOB showed good growth when cultured on lignocellulosic substrates and utilized $90-100 \%$ of lignin-related aromatic compounds. Nevertheless, Bacillus megaterium SBS3 has also been reported for its biodegradation potential on phenol and benzene [27]. In terms of polymer degradation, Bacillus megaterium strain is also involved in the biodegradation of low-density polyethylene (LDPE) [28]. This bacterium strain also has large potential in the degradation process for biodegradable natural rubber latex film [29]. 


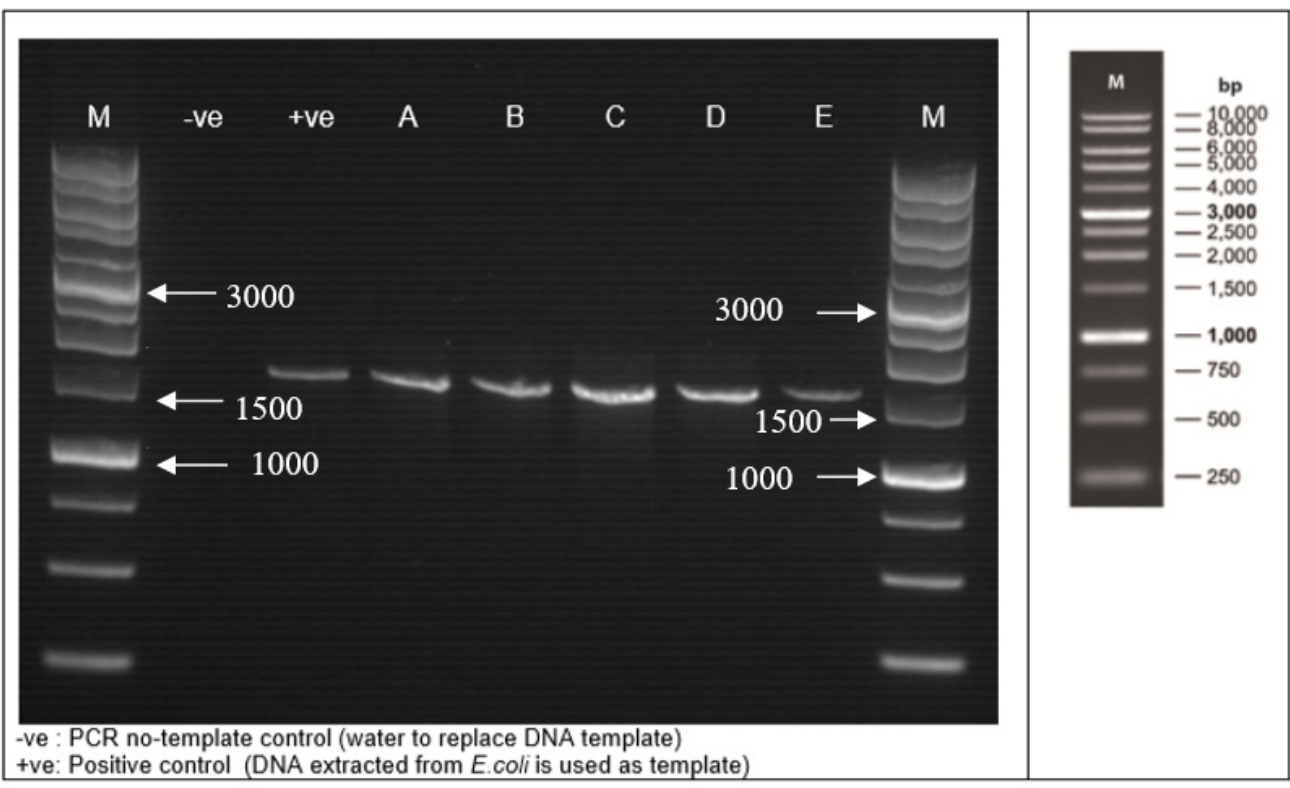

Figure 4 Visualisation of the PCR products of 16 S rRNA gene of 5 selected colonies labelled A, B, C, D and $\mathrm{E}$ on agarose gel.

Table 1 The BLAST results of $16 \mathrm{~S}$ rRNA sequencing based on isolate A, B, C, D and E.

\begin{tabular}{|c|c|c|c|c|c|c|}
\hline Description & $\begin{array}{l}\text { Max } \\
\text { score }\end{array}$ & $\begin{array}{l}\text { Total } \\
\text { score }\end{array}$ & $\begin{array}{l}\text { Query } \\
\text { cover }\end{array}$ & E value & Ident & Accession \\
\hline $\begin{array}{l}\text { B. aryabhattai strain C48 16S } \\
\text { ribosomal RNA gene. }\end{array}$ & 2747 & 2747 & $100 \%$ & 0.0 & $99 \%$ & KY 855373.1 \\
\hline $\begin{array}{l}\text { B. megaterium strain MP8 16S } \\
\text { ribosomal RNA gene. }\end{array}$ & 2747 & 2747 & $100 \%$ & 0.0 & $99 \%$ & KX 298860.1 \\
\hline $\begin{array}{l}\text { B. aryabhattai strain IHB } 11068 \\
\text { 16S ribosomal RNA gene. }\end{array}$ & 2747 & 2747 & $100 \%$ & 0.0 & $99 \%$ & KR 085848.1 \\
\hline $\begin{array}{l}\text { B. megaterium strain IHB B } 7295 \\
16 \mathrm{~S} \text { ribosomal RNA gene. }\end{array}$ & 2747 & 2747 & $100 \%$ & 0.0 & $99 \%$ & KJ 767362.1 \\
\hline $\begin{array}{l}\text { Bacillus sp. (in: Bacteria) MH9 } \\
\text { gene for } 16 \mathrm{~S} \text { ribosomal RNA, } \\
\text { partial sequence }\end{array}$ & 2747 & 2747 & $100 \%$ & 0.0 & $99 \%$ & LC373523.1 \\
\hline
\end{tabular}


a)

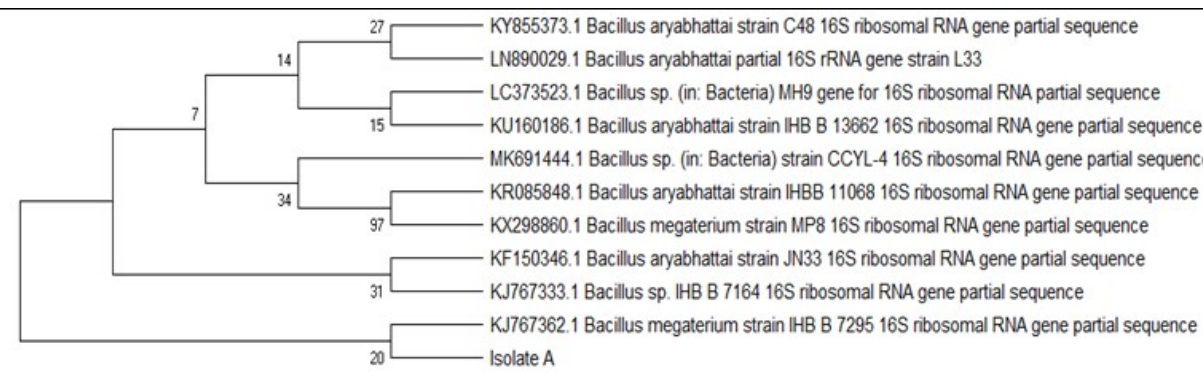

b)

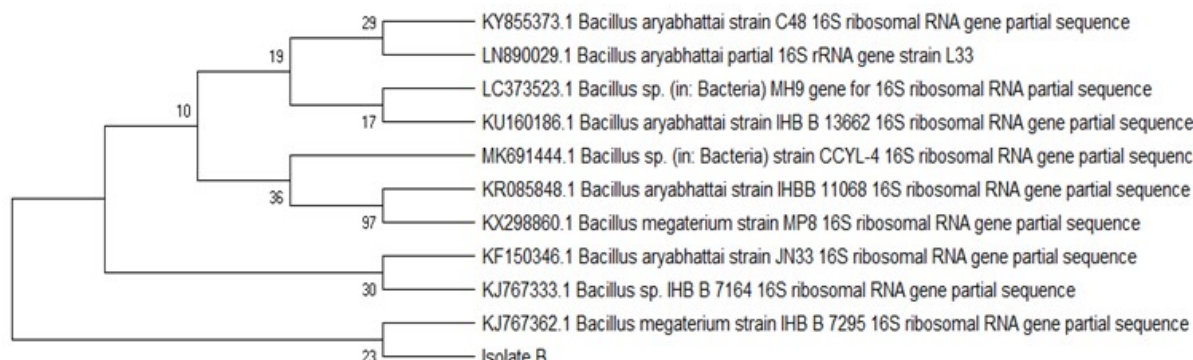

c)

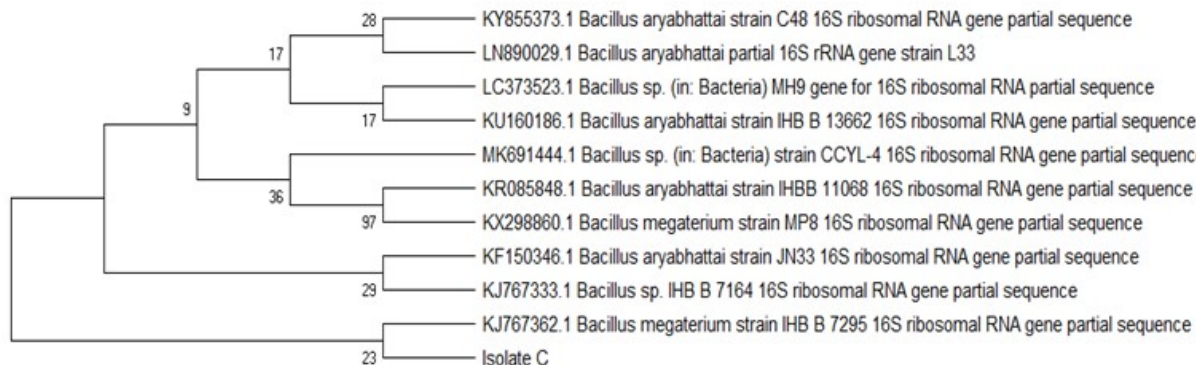

${ }_{23} \longrightarrow$ Isolate C

d)

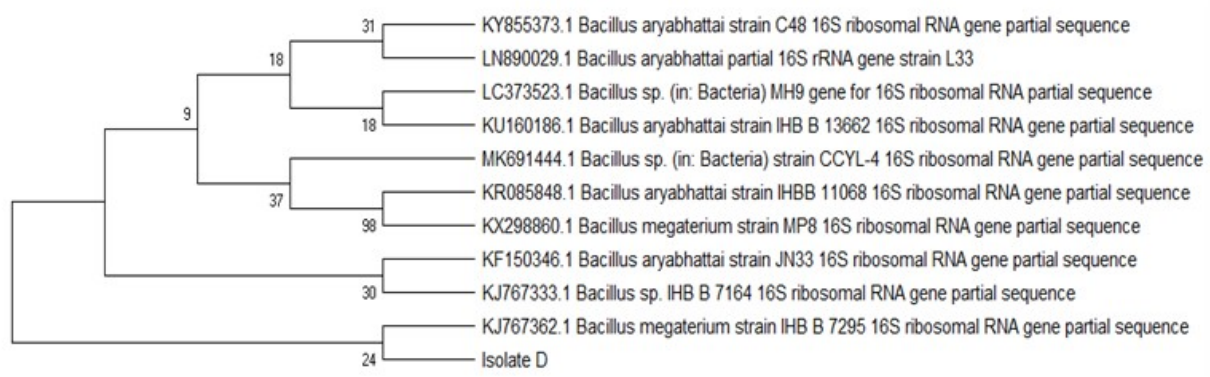

e)

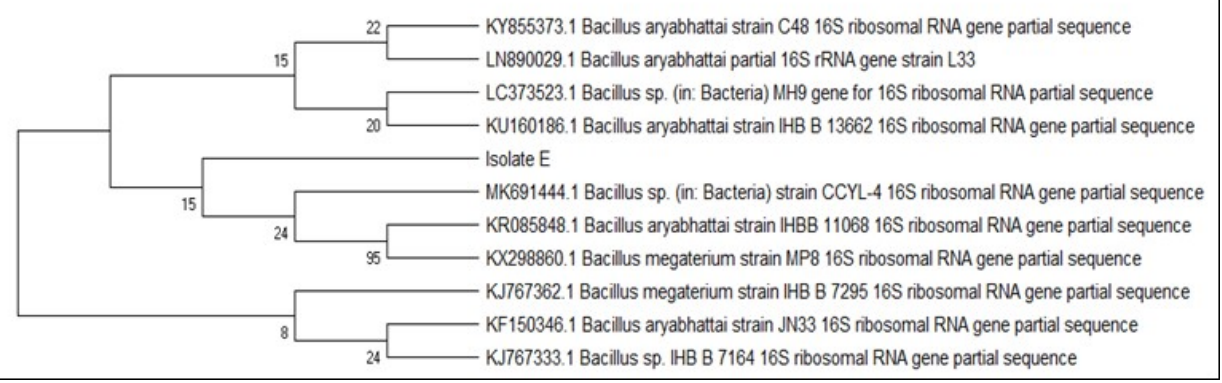

Figure 5 Phylogenetic dendrograms of the identified strains. From the above, (a) phylogenetic tree for isolate $A$, (b) phylogenetic tree for isolate $B,(c)$ phylogenetic tree for isolate $C$, (d) phylogenetic tree for isolate $\mathrm{D}$ and (e) phylogenetic tree for isolate $\mathrm{E}$ using neighbour-joining method. 
http://wjst.wu.ac.th

The reduction test of tetrazolium salts to colour formazan has been widely used as an indicator of cell metabolism in microbiology studies. This study applied the TTC reduction test for its rapid and effective analysis to verify PS-degrading bacteria's viability. The 2,3,5-triphenyltetrazolium chloride (TTC) viability test showed that the colourless TTC was readily reduced to red-coloured triphenyl formazan (TPF) by the bacterial electron transport system (ETS) with a positive-control-glucose sample after one day of incubation. Whereas, for PS added sample, the medium started to turn red after four days of incubation, and the red colour changed darker and stopped after 14 days of incubation (Figure 6). The red color formation (reduction of TTC to TPC) indicated that metabolism activities as Bacillus megaterium utilise PS as a carbon source. This can be postulated that TTC functions as an artificial electron acceptor to replace oxygen as the final $\mathrm{H}+/ \mathrm{e}$ - acceptor and is reduced by the aerobic cytochrome system into a water-insoluble, red-coloured formazans through microbial enzymatic activities [30].

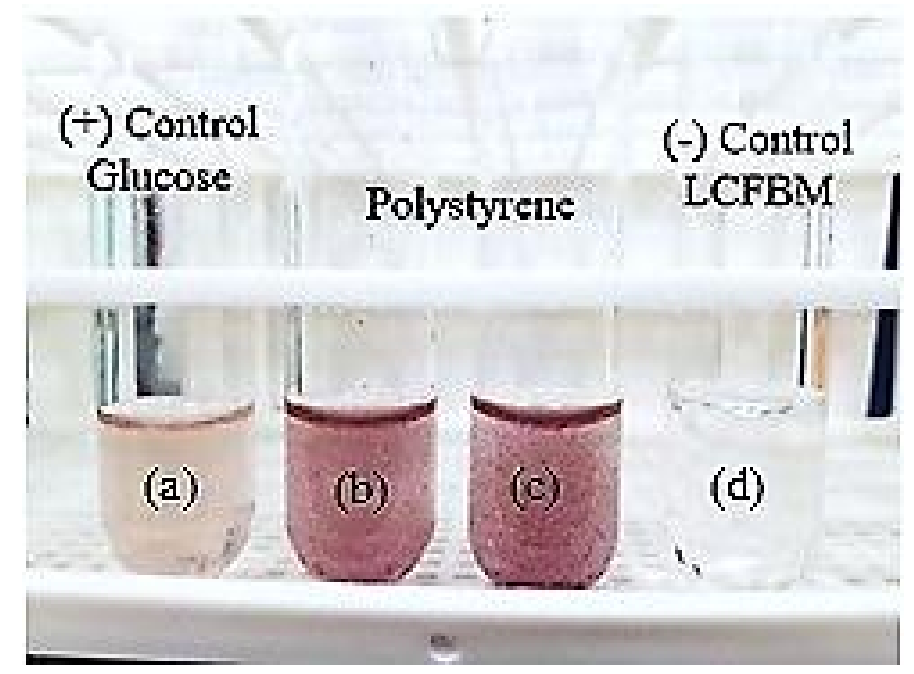

Figure 6 The metabolic activity of Bacillus megaterium measured by the reduction of TTC to TPF: (a) positive control glucose added, (b) and (c) duplicated samples of emulsified PS as sole carbon source and (d) negative control without inoculum.

The difference in the red colour intensity between the glucose added sample and PS was determined by the amount of vital cells present in the medium. More vital cells resulted in a darker red colour [31]. It is also noted that the bacteria's metabolism activity began to slow down once the limited simple form of carbon source ( $2 \%$ glucose) has been utilised completely. Whereas PS, a more complex polymer, required a longer time to be broken down into short-chain monomers that can readily permeate through the cell wall and utilised by bacteria as a carbon source to grow [32]. The bacterial growth in both control and experimental samples was soon terminated by accumulating metabolic inhibitors in the medium. Hence, the result obtained clearly demonstrated that the viability and growth of Bacillus megaterium has taken place in the presence of polystyrene as the sole carbon source. This result has concurred with the TTC reduction test, which was used as a viability indicator to study microbial degradation of low-density polyethylene [33] and high impact polystyrene (HIPS) [19]. 
http://wjst.wu.ac.th

\section{Conclusions}

The partial sequencing of the $16 \mathrm{~S}$ rRNA gene showed that bacterial colonies grown on basal PSagar plate were identified as belonging to rhizosphere bacteria Bacillus megaterium strain. At the preliminary stage, the bacterial isolates (A, B, C, D, and E) have shown PS-degrading activity. They are able to utilize PS as sole carbon in their metabolism as tested by using TTC reagent as viability indicator. Currently, information about this strain seems to be scarce, with almost no references to Bacillus megaterium on its PS-degrading potential. Nevertheless, research studies discussed above offer new insight into this strain in degrading aromatic compounds found in PS. Further studies characterization on the bacterial species for its biodegradation ability is essential and helpful in developing effective plastic waste management. In the near future, it is believed many plastic-degrading microorganisms will be identified as feasible agents to reduce the quantity of solid plastic waste, which is rapidly accumulating in the natural environment.

\section{Acknowledgements}

The authors would like to thank the Postgraduate Research Grants (GPPS U769) Universiti Tun Hussein Onn Malaysia (UTHM). Authors also gratefully appreciate the laboratory representatives from Department of Chemical Engineering Technology, Faculty of Engineering Technology i.e. Mohd Redzuan Mohd Nor, Masayu Maslan and Aziah Abu Samah for their help and technical support in this project.

\section{References}

[1] A Pariatamby. Country chapter state of the 3Rs in Asia and the Pacific-Malaysia. United Nations Centre for Regional Development, Nagoya, 2017.

[2] Malaysia targets nationwide ban on plastic bags within a year: Minister. Available at: https://www.channelnewsasia.com/news/asia/malaysia-targets-nationwide-ban-on-plastic-bagswithin-a-year-10283100, accessed April 2020.

[3] OC Aja and HH Al-Kayiem. Review of municipal solid waste management options in Malaysia, with an emphasis on sustainable waste-to-energy options. J. Mater. Cy. Waste Manag. 2014; 16, 693-710.

[4] Ministry of Energy, Science, Technology, Environment \& Climate Change. Malaysia's roadmap towards zero single-use plastics 2018-2030: Towards a sustainable future. Routledge, Abingdon, 2018.

[5] SAS Abd Kadir, CY Yin, MR Sulaiman, X Chen and M El-Harbawi. Incineration of municipal solid waste in Malaysia: Salient issues, policies and waste-to-energy initiatives. Renew. Sustain. Energ. Rev. 2013; 24, 181-6.

[6] A Fazeli, F Bakhtvar, L Jahanshaloo, NA Che Sidik and AE Bayat. Malaysia's stand on municipal solid waste conversion to energy: A review. Renew. Sustain. Energ. Rev. 2016; 58, 1007-16.

[7] M Sharma, P Sharma, A Sharma and S Chandra. Microbial degradation of plastic: A brief review. CIBTech J. Microbiol. 2015; 4, 85-9.

[8] T Higashimura, M Sawamoto, T Hiza, M Karaiwa, A Tsuchii and T Suzuki. Effect of methyl substitution on microbial degradation of linear styrene dimers by two soil bacteria. Appl. Environ. Microbiol. 1983; 46, 386-91.

[9] O Milstein, R Gersonde, A Huttermann, MJ Chen and JJ Meister. Fungal biodegradation of lignopolystyrene graft copolymers. Appl. Environ. Microbiol. 1992; 58, 3225-32.

[10] K Nakamiya, T Ooi and S Kinoshita. Non-Heme hydroquinone peroxidase from Azotobacter beijerinckii HM121. J. Ferment. Bioeng. 1997; 84, 14-21.

[11] R Mor and A Sivan. Biofilm formation and partial biodegradation of polystyrene by the actinomycete Rhodococcus ruber: Biodegradation of polystyrene. Biodegradation 2008; 19, 851-8.

[12] Y Yang, J Chen, WM Wu, J Zhao and J Yang. Complete genome sequence of Bacillus sp. YP1, a polyethylene-degrading bacterium from waxworm's gut. J. Biotechnol. 2015; 200, 77-8. 
http://wjst.wu.ac.th

[13] J Riudavets, I Salas and MJ Pons. Damage characteristics produced by insect pests in packaging film. J. Stored Prod. Res. 2007; 43, 564-70.

[14] J Yang, Y Yang, WM Wu, J Zhao and L Jiang. Evidence of polyethylene biodegradation by bacterial strains from the guts of plastic-eating waxworms. Environ. Sci. Tech. 2014; 48, 13776-84.

[15] Y Yang, J Yang, WM Wu, J Zhao, Y Song, L Gao, R Yang and L Jiang. Biodegradation and mineralization of polystyrene by plastic-eating mealworms: Part 2. Role of gut microorganisms. Environ. Sci. Tech. 2015; 49, 12087-93.

[16] AA Shah, T Eguchi, D Mayumi, S Kato, N Shintani, NR Kamini and T Nakajima-Kambe. Purification and properties of novel aliphatic-aromatic co-polyesters degrading enzymes from newly isolated Roseateles depolymerans strain TB-87. Polym. Degrad. Stabil. 2013; 98, 609-18.

[17] Z Tang, T-AK Kuo and H Liu. The Study of the microbes degraded polystyrene. Adv. Tec. Innovat. $2017 ; 2,13-7$.

[18] K Tamura, D Peterson, N Peterson, G Stecher, M Nei and S Kumar. MEGA5: Molecular evolutionary genetics analysis using maximum likelihood, evolutionary distance, and maximum parsimony methods. Mol. Biol. Evol. 2011; 28, 2731-9.

[19] AJ Mohan, VC Sekhar, T Bhaskar and KM Nampoothiri. Microbial assisted High Impact Polystyrene (HIPS) degradation. Bioresour. Tech. 2016; 213, 204-7.

[20] NA Logan and PD Vos. Bacillus. Bergey's Manual of Systematics of Archaea and Bacteria. John Wiley \& Sons Ltd, Chichester, 2015, p. 1-163.

[21] CE Aruw and ST Ogunlade. Classical identification, 16 S rDNA sequencing and molecular characterization of Bacillus species from convenience foods. Int. J. Biochem. Bioinform. Biotechnol. Stud. 2018; 3, 21-30.

[22] VM Pathak and Navneet. Review on the current status of polymer degradation: A microbial approach. Bioresour. Bioprocess. 2017; 4, 15.

[23] VS Cerqueira, EB Hollenbach, F Maboni, MH Vainstein, FAO Camargo, MDCR Peralba and FM Bento. Biodegradation potential of oily sludge by pure and mixed bacterial cultures. Bioresour. Tech. 2011; 102, 11003-10.

[24] B Yudono, M Said, Sabaruddin, A Napoleon and MB Utami. Kinetics of petroleum-contaminated soil biodegraded by an indigenous bacteria Bacillus megaterium. HAYATI J. Biosci. 2011; 17, $155-$ 60 .

[25] SR Patil. Production and purification of lignin peroxidase from Bacillus megaterium and its application in bioremidation. CIBTech J. Microbiol. 2014; 3, 22-8.

[26] OM Buraimoh, MO Ilori and OO Amund. Characterization of lignocellulolytic bacterial strains associated with decomposing wood residues in the Lagos lagoon, Nigeria. Malays. J. Microbiol. $2015 ; 11,273-83$.

[27] D Vijayan, J Kochupurackal, A Abraham and I Chandrasekharan Nair. Microbial consortia formulation for the effective biodegradation of benzene, toluene, xylene and phenol. J. Microbiol. Biotech. Food Sci. 2014; 3, 457-62.

[28] C Abrusci, JL Pablos, T Corrales, J Lopez-Marin, I Marin and F Catalina. Biodegradation of photodegraded mulching films based on polyethylenes and stearates of calcium and iron as pro-oxidant additives. Int. Biodeterior. Biodegrad. 2011; 65, 451-9.

[29] ZM. Tajuddin and AR Azura. Bacillus megaterium sp. as degradation agent for biodegradable natural rubber latex films. Adv. Mater. Res. 2013; 626, 813-7.

[30] K Alef and P Nannipieri. Methods in applied soil microbiology and biochemistry. Academic Press, New York, 1995.

[31] SH Moussa, AA Tayel, AA Al-Hassan and A Farouk. Tetrazolium/formazan test as an efficient method to determine fungal chitosan antimicrobial activity. J. Mycol. 2013; 2013, 753692.

[32] UD Uttiya Dey. An approach to polymer degradation through microbes. IOSR J. Pharm. 2013; 2, $385-8$.

[33] K Harshvardhan and B Jha. Biodegradation of low-density polyethylene by marine bacteria from pelagic water, Arabian Sea, India. Mar. Pollut. Bull. 2013; 77, 100-6. 